\title{
Synthesis and Properties of Multicomponent Synthetic Polypeptides ${ }^{\dagger}$
}

\author{
Yasuko Irzuka, Kaori WaKamatsu, Hiroshi Mitomo, Masanao OYA, \\ Makoto IWATSUKI, ${ }^{*}$ and Toshio HaYASHI ${ }^{* *}$ \\ Department of Biochemistry and Engineering, Faculty of Engineering, \\ Gunma University, Kiryu, Gunma 376, Japan \\ * Ajinomoto Co., Ltd., Chuo-ku, Tokyo 104, Japan \\ ** Research Center for Biomedical Engineering, Kyoto University, Sakyo-ku, Kyoto 606, Japan
}

(Received September 16, 1992)

\begin{abstract}
Copolypeptides were synthesized by the multicomponent copolymerization of $N$-carboxy- $\alpha$-amino acid anhydrides of Glu(OBzl), Phe, Leu, Cys(Bzl), Lys(Z), Orn(Z), Ala, or Gly. The copolymerization was proceeded by ideal random copolymerization. Multicomponent polypeptides obtained here were high-molecular-weight, mostly soluble in aprotic solvent, and formed films having high tensile strength and transparency.

KEY WORDS Multicomponent Copolypeptides / $N$-Carboxy- $\alpha$-amino Acid Anhydrides / Copolymerization / Conformation / Films /
\end{abstract}

High-molecular-weight synthetic polypeptides have become models for the general study of physical, chemical, and biological properties of proteins. A wide variety of methods for peptide synthesis has been proposed. ${ }^{1-5}$ There is one in which each amino acid residue is elongated stepwise and another where activated amino acid derivatives are polymerized at once. The former involves many processes, so the yield of pure product is remarkably low with increasing residue number. ${ }^{1}$ On the other hand, the latter method can give high-molecular-weight polypeptides in good yields, ${ }^{5,6}$ though it is difficult to control the amino acid sequences in these polypeptides. In one sense, naturally occurring proteins may be regarded as multicomponent polypeptides having random sequences. Here we polymerized $N$ carboxy- $\alpha$-amino acid anhydrides (NCAs) to synthesize soluble and high-molecular-weight copolypeptides having random sequences of amino acid residues. Copolypeptides thus obtained will be better models of naturally occurring proteins than homopolypeptides widely used so far.

\section{EXPERIMENTAL}

\section{Synthesis and Polymerization of NCA}

Preparation of NCAs was carried out as previously reported. ${ }^{2-4}$ NCAs were copolymerized under the conditions summarized in Tables I and II at $30^{\circ} \mathrm{C}$ for $144 \mathrm{~h}$ (Scheme 1). Residual NCAs were monitored by titrating $\mathrm{CO}_{2}$ by sodium methoxide in a mixture of ehtanol and dioxane by the method of Katchalski and Shalitin. ${ }^{7,8}$

\section{Amino Acid Analysis}

Amino acid compositions of copolypeptides were determined from a peak intensity of each proton in an NMR spectrum of the copolypeptide in solution, ${ }^{9-11}$ or by an amino acid analysis of hydrolyzates of the copolymer. It

† A part of this work was presented at IUPAC32nd International Symposium on Macromolecules: Kyoto Japan, August 1-6, 1988, Abstracts No. 4.9.16. 


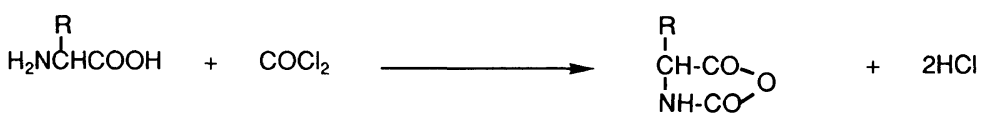





Scheme 1.

was impossible to completely hydrolyze these copolymers to amino acids by the generally used method where a polymer is hydrolyzed in $11 \mathrm{~N} \mathrm{HCl}(8 \mathrm{ml})$ at $110^{\circ} \mathrm{C}$ for $96 \mathrm{~h}$ in sealed glass tube. Therefore, the copolypeptides $(100 \mathrm{mg})$ were first hydrolyzed in $11 \mathrm{~N} \mathrm{HCl}$ $(8 \mathrm{ml})$ at $100^{\circ} \mathrm{C}$ for $48 \mathrm{~h}$ in a sealed glass tube. The solvent was removed under a reduced pressure. Then the residue was hydrolyzed in the mixture of trifluoroacetic acid $(6.4 \mathrm{ml})$ and $11 \mathrm{~N} \mathrm{HCl}(1.6 \mathrm{ml})$ at $90^{\circ} \mathrm{C}$ for $48 \mathrm{~h}$ in a sealed tube.

Proton NMR spectra were recorded on a Bruker AM-400 spectrometer. A two-dimensional HOHAHA (Homonuclear HartmannHarn $)^{12}$ spectrum used for the assignment of proton resonances is shown in Figure 1.

Optical Rotatory Dispersion (ORD) and Circular Dichroism $(C D)$

ORD spectra of polymerization solutions were measured on a JASCO J-20A at wavelength from 650 to $250 \mathrm{~nm}$ at about $20-25^{\circ} \mathrm{C}$ after completion of polymerization. A Moffit parameter $b_{0}$ was calculated by reference to the literature. ${ }^{13,14}$

$\mathrm{CD}$ spectrum of the copolypeptide was measured on a JASCO J-20A at wavelength from 300 to $190 \mathrm{~nm}$ at $21-23^{\circ} \mathrm{C}$, using $0.1 \mathrm{~mm}$ path length cell at a concentration of about $3 \times 10^{-4} \mathrm{~mol} \mathrm{~cm}^{-3}$ (residue basis) in $1,1,1,3,3,3$ hexafluoro-2-propanol (HFIP). The reduced mean residue ellipticity, $\left[\theta^{\prime}\right]$ was calculated by reference to the literature. ${ }^{15}$

\section{Infrared (IR)}

IR spectra were recorded on a JASCO 701 infrared spectrometer on films of polypeptides. The conformations of the copolypeptides were determined by inspecting absorption in the amide-I, -II, and $-\mathrm{V}$ regions together with absorption in the far-IR region.

$X-R a y$

$\mathrm{X}$-Ray diffraction diagrams were obtained by film method by using a Shimadzu diffraction meter with nickel filtered $\mathrm{Cu}-K_{\alpha}$ radiation.

\section{Differential Scanning Calorimetry (DSC)}

The DSC of the copolypeptides was carried out at a sample heating rate of $10^{\circ} \mathrm{C} \mathrm{min}^{-1}$ in a SEIKO DS- 10.

\section{Viscosity Measurement}

The viscosities of the copolypeptides were measured in a solution of dichloroacetic acid using an Ostwald viscometer at $30^{\circ} \mathrm{C}^{6}$

\section{Solubility of Polypeptide}

Solubility of the copolypeptides in solvents was determined as follows. Eight to fifteen milligrams of the polypeptide were put into $5 \mathrm{ml}$ of various solvents (methylene chloride, benzene, dimethyl sulfoxide, or ethyl acetate). 
Table I. Multicomponent polymerization of $N$-carboxy- $\alpha$-amino acid anhydrides in acetonitrile ${ }^{\mathrm{a}}$

\begin{tabular}{|c|c|c|c|c|c|c|}
\hline \multirow{2}{*}{ No. } & \multirow{2}{*}{$\frac{\text { Component of fed NCAs }}{\text { mol } \%}$} & \multirow{2}{*}{$\frac{\text { Yield of polymer }}{\%}$} & \multicolumn{2}{|c|}{$\mathrm{CD}^{\mathrm{b}}$} & \multirow{2}{*}{$\eta_{\mathrm{sp}} / c^{\mathbf{c}}$} & \multirow{2}{*}{ Solubility $^{\mathrm{d}}$} \\
\hline & & & $\lambda / \mathrm{nm}$ & {$\left[\theta^{\prime}\right]$} & & \\
\hline & Leu : Pro: Phe : Cys(Bzl) : Glu(OBzl) & 93 & 220 & -18800 & 0.54 & A \\
\hline & $21.4: 10.4: 21.4: 10.7: 36.5$ & & 208 & -21600 & & \\
\hline & Leu : Pro: Phe : Glu(OBzl) & 98 & 220 & -15200 & 0.62 & A \\
\hline & $23.9: 11.8: 23.9: 40.7$ & & 207 & -18300 & & \\
\hline & Gly: Ala : Leu : Phe : Glu(OBzl) : Lys(Z) & 87 & 216 & -18500 & 0.93 & A \\
\hline & $21.5: 30.2: 12.7: 9.9: 16.8: 9.1$ & & 205 & -22100 & & \\
\hline & Gly: Ala : Leu : Phe : Cys(Bzl) : Glu(OBzl) : Lys(Z) & 84 & 218 & -18600 & 0.44 & $A \#$ \\
\hline & $20.9: 19.8: 13.0: 9.6: 10.2: 17.6: 8.9$ & & 207 & -15300 & & \\
\hline & Gly: Ala: Leu :Cys(Bzl) : Glu(OBzl) & 98 & 218 & -15300 & 0.35 & $A \#$ \\
\hline & $23.9: 22.6: 14.9: 11.6: 27.0$ & & 207 & -18900 & & \\
\hline & $\begin{array}{l}\text { Gly: Ala : Leu : Cys(Bzl) }: \text { Glu(OBzl) }: \text { Lys(Z) } \\
19.8: 18.7: 12.3: 9.6: 23.5: 16.0\end{array}$ & 83 & & & & $A \#$ \\
\hline & $\begin{array}{l}\text { Gly: Ala : Leu : Phe : Glu(OBzl) }: \text { Lys(Z) } \\
21.5: 30.2: 12.7: 9.9: 16.8: 9.1^{\mathrm{e}}\end{array}$ & 90 & & & 1.40 & AA\# \\
\hline
\end{tabular}

a Abbreviations of amino acids and their derivatives in this paper are those recommended by the IUPAC-IUB Commission on Biochemical Nomenclature. In this table abbreviations of NCA are cut. NCAs were polymerized with NCA $/ 200 \mathrm{~mol} \%$ of triethylamine at the concentration about $0.03 \mathrm{moll}^{-1}$ at $30^{\circ} \mathrm{C}$ for $168 \mathrm{~h}$.

b $c, 2.0 \mathrm{mg} \mathrm{ml}^{-1}$ in 1,1,3,3,3-hexafluoro-2-propanol (HFIP); [ $\left.\theta^{\prime}\right], \mathrm{deg} \mathrm{cm}^{2} \mathrm{decimol}^{-1}$; reflect index of HFIP, 1.297.

c $c, 0.5 \mathrm{mg} \mathrm{ml}^{-1}$ in dichloroacetic acid.

d A, soluble in dichloroacetic acid, A\#, swelling in 1,2-dichloroethane; AA\#, soluble in 1,2-dichloroethane.

e Copolymerization in 1,2-dichloroethane. NCA compositions are same as No. 3.

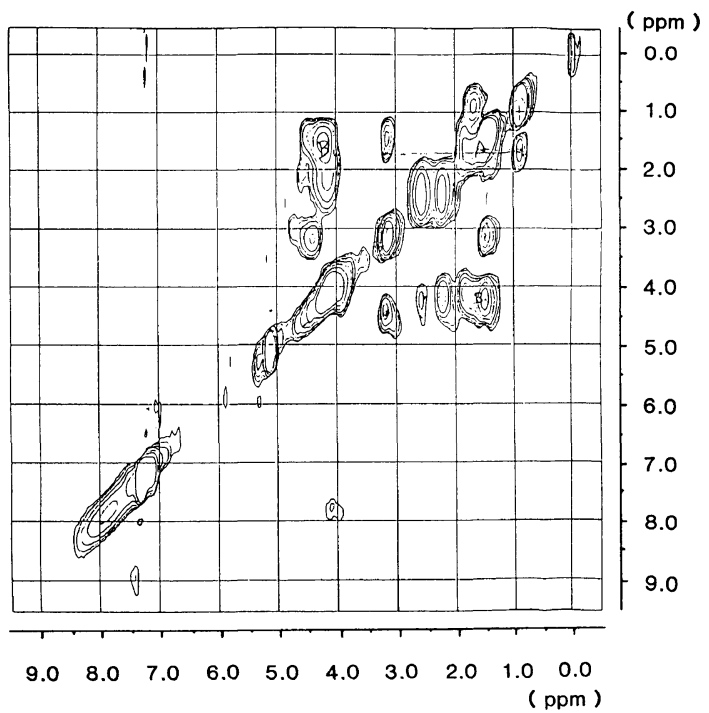

Figure 1. Two-dimensional ${ }^{1} \mathrm{H}$ NMR spectrum of poly(Gly, Ala, Leu, Phe, Glu(OBzl), Lys(Z)); No. 3 listed in Table I.
After $24 \mathrm{~h}$ at room temperature, the presence of residue was inspected visually.

\section{Film Strength}

The films of the copolypeptides were made by drying the polymerization solution on a flat glass plate. The films of $10-15 \mathrm{~mm}$ width and $0.05 \mathrm{~mm}$ thick obtained here were used for measurement of tensile strength by a Tensilon UTM-I of Toyo Baldwin Co., Ltd.

\section{RESULTS AND DISCUSSION}

\section{Polymerization}

Properties of the copolypeptides, containing from five to seven kinds of amino acid residues obtained by the multicomponent copolymerization of NCAs in acetonitrile or 1,2dichloroethane as a polymerization solvent are summarized in Tables I and II, respectively. Higher-molecular-weight copolypeptides were often obtained by the multicomponent polym- 
Table II. Multicomponent polymerization of $N$-carboxy- $\alpha$-amino acid anhydrides in 1,2-dichloroethane ${ }^{a}$









erization of various kinds of NCAs than by polymerization of one kind of NCA. In acetonitrile the copolypeptides were obtained as precipitate, while in 1,2-dichloroethane the copolypeptides were soluble in the solvent. It was difficult to estimate exactly monomer reactivity ratios in the multicomponent polymerization reaction by the Mayo-Lewis equation. Amino acid compositions of some polypeptides were determined from peak intensity of each proton resonance in one- dimensional NMR spectrum. Proton chemical shifts of polymer No. 3 in Table I as assigned by a two-dimensional HOHAHA spectrum (Figure 1) are listed in Table III. Amino acid composition was also determined by amino acid analysis on the hydrolyzate for some copolypeptides. The results are summarized in Table IV. Amino acid compositions in copolypeptides were almost same as in NCA mixtures fed in all combinations of NCAs both in acetonitrile and in 1,2-dichloroethane.

Table III. Chemical shifts of amino acid residues assigned by two-dimensional NMR

\begin{tabular}{|c|c|c|c|c|c|c|c|c|}
\hline \multirow{2}{*}{$\begin{array}{l}\text { Shift } \\
\text { ppm }\end{array}$} & \multicolumn{8}{|c|}{ Amino acid } \\
\hline & Gly & Ala & Leu & Phe & $\mathrm{Glu}(\mathrm{OBzl})$ & Lys(Z) & Cys(Bzl) & Group \\
\hline 0.96 & & & $\delta\left(\mathrm{CH}_{3}\right)_{2}$ & & & & & 1 \\
\hline 1.52 & & & & & & $\gamma \mathrm{CH}_{2}$ & & \\
\hline 1.59 & & $\mathrm{CH}_{3}$ & & & & & & \\
\hline 1.71 & & & & & & $\delta \mathrm{CH}_{2}$ & & 2 \\
\hline 1.80 & & & $\gamma \mathrm{CH}$ & & & & & \\
\hline 1.80 & & & $\beta \mathrm{CH}_{2}$ & & & & & \\
\hline 1.94 & & & & & & $\beta \mathrm{CH}_{2}$ & & \\
\hline 2.24 & & & & & $\beta \mathrm{CH}$ & & & 3 \\
\hline 2.28 & & & & & $\beta \mathrm{CH}$ & & & \\
\hline 2.64 & & & & & $\gamma \mathrm{CH}_{2}$ & & & 4 \\
\hline 2.86 & & & & & & & $\beta \mathrm{CH}_{2}$ & 5 \\
\hline 3.06 & & & & & & $\varepsilon \mathrm{CH}_{2}$ & & \\
\hline 3.26 & & & & $\beta \mathrm{CH}$ & & & & 6 \\
\hline 3.33 & & & & $\beta \mathrm{CH}$ & & & & \\
\hline 3.70 & & & & & & & $\mathrm{BzlCH}_{2}$ & 7 \\
\hline 3.94 & $\mathrm{CH}_{2}$ & & & & & & & \\
\hline 4.07 & & & $\alpha \mathrm{CH}$ & & & & & \\
\hline 4.08 & & & & & & $\alpha \mathrm{CH}$ & & \\
\hline 4.16 & & & & & $\alpha \mathrm{CH}$ & & & 8 \\
\hline 4.20 & & $\alpha \mathrm{CH}$ & & & & & & \\
\hline 4.31 & & & & & & & $\alpha \mathrm{CH}$ & \\
\hline 4.38 & & & & $\alpha \mathrm{CH}$ & & & & \\
\hline 5.10 & & & & & & $\mathrm{ZCH}_{2}$ & & 9 \\
\hline 5.10 & & & & & $\mathrm{BzlCH}_{2}$ & & & \\
\hline 7.37 & & & & $\mathrm{C}_{6} \mathrm{H}_{5}$ & & & $\mathrm{C}_{6} \mathrm{H}_{5}$ & 10 \\
\hline 7.40 & & & & & $\mathrm{C}_{6} \mathrm{H}_{5}$ & $\mathrm{C}_{6} \mathrm{H}_{5}$ & & \\
\hline
\end{tabular}


Multicomponent Polypeptides

Table IV. Amino acid compositions (in mol\%) of copolypeptides

\begin{tabular}{|c|c|c|c|c|c|c|c|c|c|c|}
\hline & & Gly & Ala & Leu & Phe & Glu(OBzl) & Lys(Z) & Cys(Bzl) & Solvent $^{\mathrm{a}}$ & Method $^{d}$ \\
\hline \multirow{2}{*}{ No. 3} & \multirow{2}{*}{$\begin{array}{l}\text { NCAs fed } \\
\text { in Polymer }\end{array}$} & 21.5 & 30.2 & 12.7 & 9.6 & 16.8 & 9.1 & 0 & \multirow{2}{*}{$\mathrm{ACN}$} & \\
\hline & & 21.0 & 33.9 & 13.8 & 8.7 & 14.5 & 9.1 & 0 & & NMR \\
\hline \multirow[t]{3}{*}{ No. 4} & \multirow{3}{*}{$\begin{array}{l}\text { NCAs fed } \\
\text { in Polymer }\end{array}$} & 20.9 & 19.8 & 13.0 & 9.6 & 17.6 & 8.9 & 10.2 & \multirow[t]{3}{*}{$\mathrm{ACN}$} & \\
\hline & & 16.3 & 21.2 & 15.0 & 10.3 & 19.2 & 10.7 & 9.4 & & NMR \\
\hline & & 22.5 & 22.5 & 15.8 & 5.8 & 15.2 & 8.5 & $10.2^{c}$ & & $\mathrm{AAA}$ \\
\hline \multirow[t]{2}{*}{ No. 5} & \multirow{2}{*}{$\begin{array}{l}\text { NCAs fed } \\
\text { in Polymer }\end{array}$} & 23.9 & 22.6 & 14.9 & 0 & 27.0 & 0 & 11.6 & \multirow[t]{2}{*}{$\mathrm{ACN}$} & \\
\hline & & 24.7 & 22.6 & 15.1 & 0 & 26.2 & 0 & 11.6 & & NMR \\
\hline \multirow[t]{2}{*}{ No. 6} & \multirow{2}{*}{$\begin{array}{l}\text { NCAs fed } \\
\text { in Polymer }\end{array}$} & 19.8 & 18.7 & 12.3 & 0 & 23.5 & 16.0 & 9.6 & \multirow[t]{2}{*}{ ANC } & \\
\hline & & 18.4 & 20.2 & 12.9 & 0 & 22.1 & 15.8 & $10.1^{\mathrm{c}}$ & & AAA \\
\hline \multirow[t]{2}{*}{ No. 7} & \multirow{2}{*}{$\begin{array}{l}\text { NCAs fed } \\
\text { in Polymer }\end{array}$} & 21.5 & 30.2 & 12.7 & 9.9 & 16.8 & 9.1 & 0 & \multirow[t]{2}{*}{ DCE } & \\
\hline & & 21.0 & 33.9 & 13.8 & 8.7 & 14.5 & 9.1 & 0 & & NMR \\
\hline
\end{tabular}

a ACN, acetonitrile; DCE, 1,2-dichloroethane.

b NMR, determined by NMR; AAA, determined by amino acid analysis.

c Calculated by elemental analysis of sulfur: No. 4, 3.4\%; No. 6, 3.3\% by a amino acid analyzer HITACHI 850 -S.

Therefore, it is suggested that the reaction proceeds by the ideal random copolymerization in acetonitrile and in 1,2-dichloroethane.

In two-component polymerization, a pair of $\delta$-benzyl L-glutamate NCA (Glu(OBzl) NCA) and $\varepsilon$-carbobenzoxyl L-lysine NCA (Lys(Z) NCA) tend to produce a block copolypeptide, ${ }^{7}$ while a pair of L-leucine NCA (Leu NCA) and DL-alanine NCA (DL-Ala NCA), and a pair of glycine NCA (Gly NCA) and L-alanine NCA (Ala NCA), ${ }^{3,16}$ tend to be copolymerized in alternate arrangement. On the other hand, the copolymerizations of three components of NCAs such as $S$-carbobenzoxy L-cystein NCA (Cys(Bzl) NCA), Ala NCA, and Glu(OBzl) NCA mostly proceed by the ideal random copolymerization reaction. ${ }^{17}$ The copolymerizations of NCAs with more than three components seem to proceed by ideal copolymerization.

\section{Solubility of Multicomponent Polypeptides}

Solubility of multicomponent polypeptides is shown in Table II. Most multicomponent polypeptides obtained here were insoluble in acetonitrile but soluble in HFIP.

\section{Conformation of Copolypeptides}

CD spectra of the copolypeptides listed in Table I in the HFIP solution are shown in Figures $2 \mathrm{~A}$ and $2 \mathrm{~B}$. These patterns with two minima at 207 and $222 \mathrm{~nm}$ are characteristic of the $\alpha$-helical conformation. ${ }^{15}$ The $\alpha$-helix contents of copolymers No. 1 and No. 2 were calculated from their $\left[\theta^{\prime}\right]$ values at 207 and $222 \mathrm{~nm}$ as $40-50 \%$ and $30-40 \%$, respectively, by referencing that the $100 \% \alpha$-helical poly(L-lysine) shows $\left[\theta^{\prime}\right]$ values of -37000 and -40000 at 207 and $222 \mathrm{~nm} .{ }^{15}$ When NCAs were copolymerized in 1,2-dichloroethane, the copolyeptides were soluble in the solvent (Table II). Structures of the copolypeptides in the polymerization solution were estimated to be $\alpha$-helical or random coil structures from the Moffit parameter $b_{0}$ of ORD spectra (Table II). The parameter $b_{0}$ takes -630 for $100 \%$ $\alpha$-helix and zero for random coil. The $\alpha$-helix content of the multicomponent polypeptides depended on amino acid composition. As expected, $20 \mathrm{~mol} \%$ (but not $2 \mathrm{~mol} \%$ ) proline residue decreased $\alpha$-helix content (polymer No. 9, 12, 15, 24, and 26; Table II).

Figure 3 shows the IR spectra of films of 




Figure 2A. CD spectra of multicomponent copolypeptides $\left(c ; 2 \mathrm{mg} \mathrm{ml}^{-1}\right.$ in 1,1,1,3,3,3-hexafluoro-2-propanol (HFIP)) listed in Table I; No. 1, poly(Leu, Pro, Phe, Cys(Bal), Glu(OBzl)), -.--; No. 2, poly(Leu, Pro, Phe, Glu(OBzl)), --·; No. 3, poly(Gly, Ala, Leu, Phe, Glu(OBzl), Lys(Z)), - .

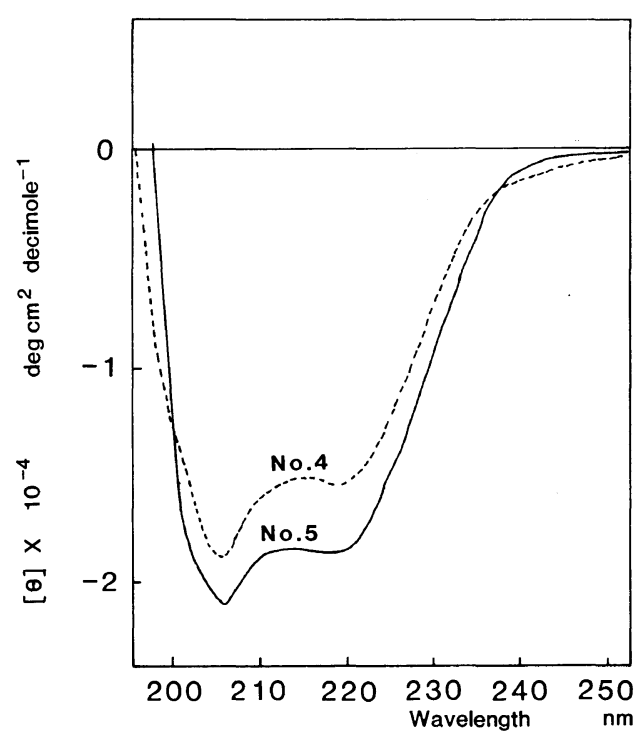

Figure 2B. CD spectra of multicomponent copolypeptides $\left(c ; 2 \mathrm{mg} \mathrm{ml}^{-1}\right.$ in 1,1,1,3,3,3-hexafluoro-2-propanol(HFIP)) listed in Table I; No. 4, poly(Gly, Ala, Leu, Phe, Cys(Bzl), Glu(OBzl), Lys(Z)), ----; No. 5, poly(Gly, Ala, Leu, Cys(Bzl), Glu(OBzl)), 一.



Figure 3. IR spectra of multicomponent copolyepeptides: No. 8, poly(Glu(OBzl), $\operatorname{Orn}(\mathrm{Z}), \operatorname{Tyr}(\mathrm{Z}), \mathrm{Phe}$, Leu); No. 14, poly(Asp(OBzl), Lys(Z), Phe, Leu, Ala). 
copolymers No. 8 and No. 14. Copolymer No. 14 in the film state showed bands at $1660-1645$ (Amide I), 1550-1540 (Amide II), and 618 (Amide V), $483 \mathrm{~cm}^{-1}$ (far-IR region), which are characteristic of the $\alpha$-helical conformation. Copolymer No. 8 in the film state showed bands at 1653 (Amide I), 1545 (Amide II), and 660, $610 \mathrm{~cm}^{-1}$ (Amide V), indicating that this copolypeptide takes a mixed conformation of $\alpha$-helix and random coil.

The conformation of each copolypeptide in the film state determined by IR was the same determined by ORD in the polymerization solution. Table II shows that copolypeptides with high $\alpha$-helix content in solution are in the $\alpha$-helical conformation in the film state. This observation indicates that conformations of copolypeptides synthesized in this study (at least, of high $\alpha$-helix content) are the same both in solution and the solid state.

$\mathrm{X}$-Ray diffraction diagrams of films of multicomponent polypeptides are shown in Figure 4. In a previous paper we reported that the X-Ray diagram of oriented poly(L-alanine) and poly(L-leucine) which form a stable $\alpha$ helical conformation showed the two strong peak at $7.4 \AA(2 \theta=11.9)$ and $4.4 \AA(2 \theta=19.6)$, and $11.9 \AA(2 \theta=7.9)$ and $4.6 \AA(2 \theta=19.5)$, respectively. ${ }^{18}$ Although most multicomponent polypeptides formed $\alpha$-helical conformations when studied by IR or ORD, diffraction diagrams of the multicomponent copolypeptides had no strong peaks. This suggests that molecules of these copolypeptides in an $\alpha$-helical conformation are not ordered.

DSC diagrams of the copolymers No. 9, 13, and 15 are shown in Figure 5. They gave only weak and broad endothermic peaks. In our previous DSC study, poly(L-Phe) which was in the crystalline state showed a sharp and intense endothermic peak at $347.0^{\circ} \mathrm{C}$, while poly(DLPhe) which did not give a crystal showed a broad endothermic peak at $390^{\circ} \mathrm{C} .{ }^{19)}$ Thus the multicomponent polypeptide molecules obtained here are not ordered although they are in the $\alpha$-helical conformation.

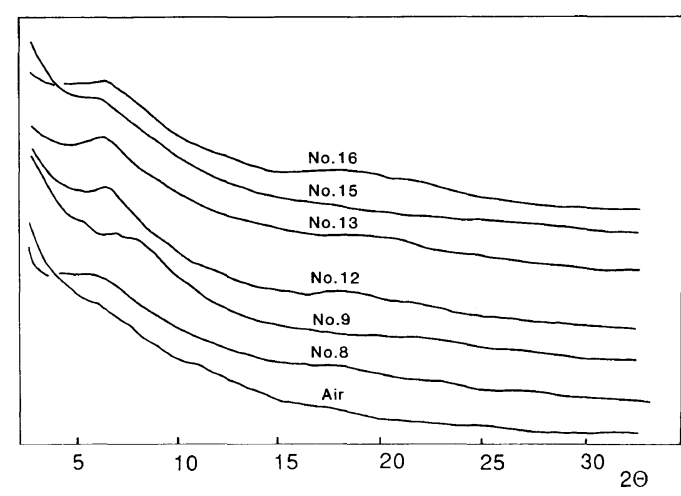

(A)

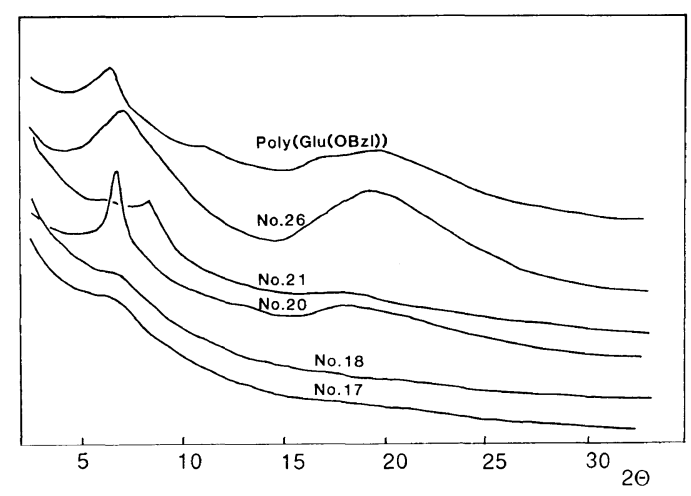

(B)

Figure 4A and B. X-Ray diffraction diagram of films of multicomponent copolypeptides listed in Table II.

\section{Viscosity of Multicomponent Polypeptides}

Although molecular-weights of the copolypeptides were high judging from their high specific viscosity in dichloroacetic acid listed in Table II, polymerization solutions in 1,2dichloroethane after the polymerization were mostly fluid. The specific viscosities of polymerization solution of copolymers No. 8, 9 , and 10 gave $1.08,0.30$, and 0.87 , at $25^{\circ} \mathrm{C}$, at the concentration of $1.90,1.70$, and $1.80 \mathrm{~g} \mathrm{dl}^{-1}$, respectively. The lower specific viscosity of the multicomponent polypeptides in 1,2-dichloroethane than in dichloroacetic acid was rather surprising since in our experience, homopolypeptides and binary copolypeptides show much higher specific viscosity in 1,2-dichloroethane than in di- 




Figure 5A. DSC diagram of multicomponent copolypeptide: No. 9, poly(Glu(OBzl), Orn(Z), Phe, Pro, Leu).



Figure 5B. DSC diagram of multicomponent copolypeptide: No. 13, poly(Asp(OBzl), $\operatorname{Orn}(Z), \operatorname{Tyr}(Z)$, Leu).

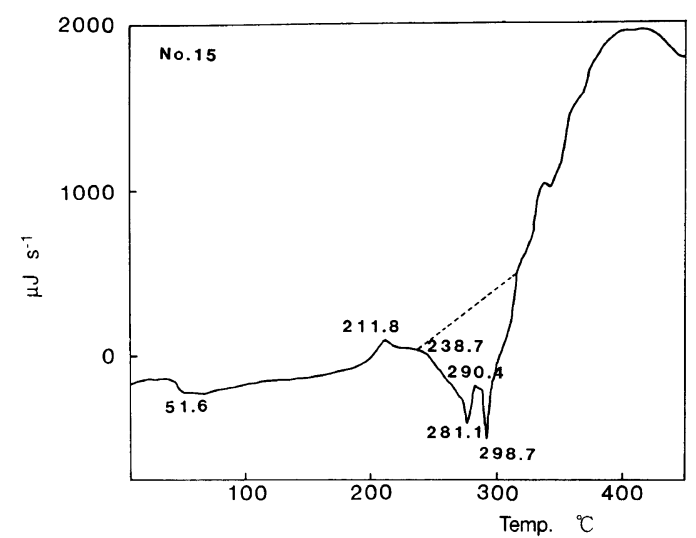

Figure 5C. DSC diagram of multicomponent copolyeptide: No. 15, poly(Asp(OBzl), Lys(Z), Phe, Pro, Leu, Ala). chloroacetic acid. For example, at $25^{\circ} \mathrm{C}$ specific viscosity of poly(Met: Asp; $1: 1$ ), was 0.68 at $0.54 \mathrm{~g} \mathrm{dl}^{-1}$ in dichloroacetic acid and 25 at $2.25 \mathrm{~g} \mathrm{dl}^{-1}$ in 1,2-dichloroethane. ${ }^{20}$ It is interesting that the dependence of visocitty on solvents is reversed between multicomponent copolypeptides and binary copolypeptides (or homopolypeptides).

\section{Films of Multicomponent Copolypeptides}

The copolypeptide films made form 1,2dichloroethane solutions were stronger and more transparent than commercial plastics, such as polyethelene and ABS resin (tensile strength of $0.7-1.6$ and $3.15 \mathrm{~kg} \mathrm{~mm}^{-2}$, respectively). Although polypeptide molecules in the films were mostly in the $\alpha$-helical conformation, they are not ordered unlike poly(L-Phe) in a crystalline state. The excellent strength and toughness of films of multicomponent polypeptides may well be due to these structure where polypeptide molecules are entangled without common orientation. Molecular segments without regular secondary structures (i.e., in random coil) probably introduced by various side chain groups are the reason for the high extensibility of the films.

Acknowledgement. We wish to thank Professor emeritus Dr. Y. Iwakura of The University of Tokyo. The present work was partially supported by a Grant-in-Aid for Scientific Research (No. 61490008) from the Ministry of Education, Science, and Culture of Japan.

\section{REFERENCES}

1. C. H. Li, "Hormonal Peptides," Vol. 2, Academic Press, New York, N.Y., 1973, p 64.

2. M. Oya and R. Katakai, in "Shin Jikken Kagaku Koza, Vol. 19 (1), Polypeptides," The Chemical Society of Japan. Ed., Maruzen Co., Tokyo, 1978, p 244.

3. M. Oya, K. Uno, and Y. Iwakura, in "Progress in Polymer Science Japan, Vol. 6: Preparation of 
Polypeptides and Oligopeptides from $N$-Carboxy- $\alpha$ amino Acid anhydrides in Acetonitrile," K. Uno and S. Onogi,, Ed., Kodansha, Tokyo, 1973, p 51.

4. E. Katchalski and M. Sela, "Advance in Protein Chemistry VIII," Academic Press, New York, N.Y., $1958, \mathrm{p} 438$.

5. M. Oya and Y. Iizuka, in "Aminosan Porima: Poriaminosan no Gousei," T. Endo, Ed., CMC, Tokyo, 1988, p 32.

6. Y. Iwakura, K. Uno, and M. Oya, J. Polym. Sci., A, 6, 216 (1967).

7. E. Katchalski, J. Am. Chem. Soc., 82, 1630 (1960).

8. Y. Shalitin, Anal. Chem., 33, 1887 (1961).

9. A. Bax and D. G. Davis, J. Magn. Reson., 65, 355 (1985).

10. G. C. K. Robert and J. O. Jardetzky, Adv. Protein Chem., 24, 477 (1970).

11. C. C. McDonald and W. D. Phillips, J. Am. Chem. Soc., 91, 1513 (1969).
12. A. Bundi, Ch. Grathwohl, J. Hochmann, R. M. Keller, G. Wagner, and K. Wuethrich, J. Magn. Reson., 18, 191 (1975).

13. J. T. Yang and P. Doty, J. Am. Chem. Soc., 79, 761 (1967).

14. G. Holzworth and P. Doty, J. Am. Chem. Soc., 87, 218 (1965).

15. R. Towned, T. F. Kumosinski, S. N. Timosheff, and G. D. Fasman, Biochem. Biophys. Res. Commum., 23, 163 (1966).

16. M. Oya, K. Uno, and Y. Iwakura, J. Polym. Sci., 10, 613 (1972)

17. Y. Iizaka, M. Oya, T. Hayashi, and M. Iwatsuki, Kobunshi Ronbunshu, 48, 246 (1991).

18. M. Oya, M. Tomizawa, K. Uno, and Y. Iwakura, Bull. Chem. Sci. Jpn., 43, 3486 (1970).

19. M. Oya, T. Endo, and Y. Iizuka, Polym. J., 20, 557 (1988).

20. M. Oya and H. Kyotani, Polym. J., 18, 513 (1986). 